Engels, G., Francke, A.L., Meijel, B. van, Douma, J.G., Kam, H. de, Wesselink, W., Houtjes, W., Scherder, E.J.A. Clinical pain in schizophrenia: a systematic review. Journal of Pain: 2014, 15(5), 457-467

\begin{tabular}{|l|l|}
\hline $\begin{array}{l}\text { Postprint } \\
\text { Version }\end{array}$ & 1.0 \\
\hline Journal website & http://www.sciencedirect.com/science/article/pii/S1526590013014223 \\
\hline Pubmed link & http://www.ncbi.nlm.nih.gov/pubmed/24365324 \\
\hline DOI & 10.1016/j.jpain.2013.11.005
\end{tabular}

This is a NIVEL certified Post Print, more info at http://www.nivel.eu

\title{
Clinical Pain in Schizophrenia: A Systematic Review
}

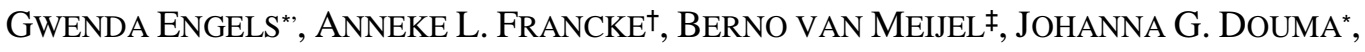 \\ HEIDI DE KAM§, WUBBIEN WESSELINK§, WIM HOUTJES", ERIK J.A. SCHERDER* \\ * Department of Clinical Neuropsychology, Vrije Universiteit, The Netherlands \\ † Netherlands Institute for Health Services Research (NIVEL) and EMGO+ VU Medical \\ Center, The Netherlands \\ ‡ Department of Health, Sports and Welfare, Cluster Nursing, Inholland University of Applied \\ Sciences and Parnassia Psychiatric Institute, The Netherlands \\ $\S$ GGz Centraal, Center for Mental Healthcare, The Netherlands \\ " GGZ-VS School for Masters of Advanced Nursing Practice, The Netherlands
}

\begin{abstract}
The number of studies about clinical pain in schizophrenia is sparse. Conclusions on pain sensitivity in people with schizophrenia are primarily based on experimental pain studies. This review attempts to assess clinical pain, that is, everyday pain without experimental manipulation, in people with schizophrenia. PubMed, PsycINFO, Embase.com, and Cochrane were searched with terms related to schizophrenia and pain. Methodological quality was assessed with the Mixed Methods Appraisal Tool. Fourteen studies were included. Persons with schizophrenia appear to have a diminished prevalence of pain, as well as a lower intensity of pain when compared to persons with other psychiatric diseases. When compared to healthy controls, both prevalence and intensity of pain appear to be diminished for persons with schizophrenia. However, it was found that this effect only applies to pain with an apparent medical cause, such as headache after lumbar puncture. For less severe situations, prevalence as well as intensity of pain appears to be comparable between people with schizophrenia and controls. Possible underlying mechanisms are discussed. Knowledge on pain in schizophrenia is important for adequate pain treatment in clinical practice.

Perspective: This review presents a valuable insight into clinical pain in people with schizophrenia.
\end{abstract}


Engels, G., Francke, A.L., Meijel, B. van, Douma, J.G., Kam, H. de, Wesselink, W., Houtjes, W., Scherder, E.J.A. Clinical pain in schizophrenia: a systematic review. Journal of Pain: 2014, 15(5), 457-467

Schizophrenia is a severe mental disorder with an estimated incidence of 15 per 100,000 persons. ${ }^{37}$ The nature of the disorder is heterogeneous, making it difficult to treat as well as investigate. Schizophrenia is mainly characterized by symptoms such as hallucinations, delusions, cognitive impairments, and avolition. ${ }^{2}$ A symptom that has received relatively little attention is the experience of pain. Various anecdotal case studies have described how clinical pain (ie, naturally occurring pain without experimental provocation) in, for example, appendicitis, fractures, and abdominal surgical emergencies seems reduced in persons with schizophrenia. A possible explanation for this finding might be a reduced sensitivity to pain in schizophrenia. ${ }^{6}$, 20, 21, 40, 41 and 44 When considering the neuropathology of schizophrenia, which is prominent in prefrontal and medial temporal areas, ${ }^{25}$ a decline in the experience of pain is plausible. This possible insensitivity to pain has been addressed in several experimental studies in persons with schizophrenia. Thermal, ${ }^{13,14}{ }^{\text {and } 16}$ electrical, ${ }^{8}$ and ${ }^{11}$ cold, $^{3}$ reflex, ${ }^{24}$ and tactile stimulation ${ }^{22}$ and 28 have been utilized to assess pain threshold and pain tolerance in schizophrenia. A considerable part, but not all, of these experimental pain studies concluded that persons with schizophrenia appear to be less sensitive to pain compared to healthy controls. ${ }^{3,} 8$ and 13 An alternative explanation might be that people with schizophrenia express pain to a lesser extent instead of experiencing a reduction in pain. ${ }^{9}$ When investigating pain, the difference between the aspects of pain should be taken into account. Pain can be divided into the sensory-discriminative aspect, mainly representing the intensity and location of pain; the motivational-affective aspect, representing the affective component of pain; and the cognitive-evaluative aspect, which integrates cognitive processes such as memory. ${ }^{38}$ The neural pathways processing these aspects might be differently affected in schizophrenia, resulting in different outcomes depending on which aspect of pain is mainly evaluated.

Results from experimental studies, which mainly test acute pain, should be considered with caution. Abilities required to judge experimental pain, such as a rapid response to express pain or evaluating feelings of pain, might be altered in schizophrenia. ${ }^{22}$ Indeed, when pain was tested with manipulations more similar to a standard medical examination, for example, a hypersensitivity to pain emerged in persons with schizophrenia. ${ }^{22}$ Pain reaction might also differ according to type of experimental manipulation (eg, electrical or ischemic pain stimulation), as appears to be the case, for example, in major depressive disorder. ${ }^{5}$ Clinical pain is the type of pain for which people seek medical help. ${ }^{45}$ Several studies suggest a differential response to clinical pain compared to experimentally induced pain. ${ }^{17,19 \text { and } 32}$ Thus, if clinical pain differs from experimentally induced pain, ${ }^{17}$ and 32 outcomes from experimental pain studies in schizophrenia might not be completely representative for clinical pain in daily life. Consequently, it seems too coarse to conclude that people with schizophrenia are less sensitive to pain in general, when only experimental pain is assessed. Taking clinical pain into account will therefore provide a more complete insight into possible alterations in pain experience in people with schizophrenia. Therefore, the goal of the present review is to address studies in which clinical pain experience in people with schizophrenia was examined. 
Engels, G., Francke, A.L., Meijel, B. van, Douma, J.G., Kam, H. de, Wesselink, W., Houtjes, W., Scherder, E.J.A. Clinical pain in schizophrenia: a systematic review. Journal of Pain: 2014, 15(5), 457-467

\section{METHODS}

Search strategies and inclusion criteria were documented in a protocol in advance. To identify articles regarding pain perception in schizophrenia, PubMed, PsycINFO, Embase.com, and Cochrane were searched until May 2013. The search strategy was based on title and abstract, MeSH terms, and thesaurus terms for schizophrenia and pain, pain perception, pain management or pain measurement. The search strategy used in PubMed can be found in Supplementary Appendix I. Specific search strategies performed in other literature databases are available on request. Additionally, reference lists of relevant publications on schizophrenia and pain were reviewed for eligible studies.

Publications were eligible for inclusion when the study assessed clinical pain experience in human adults with schizophrenia. Clinical pain is understood to mean every type of pain that has not been experimentally manipulated (eg, thermal or electrical stimulation). In order to provide a complete overview, all types of clinical pain were assessed (eg, pain after surgical interventions, pain in daily life, or chronic pain). Data analyses should be of a quantitative nature, not qualitative, meaning that analyses were performed on quantitative data. Only subjects with schizophrenia (ie, not schizoaffective disorder or psychosis) were eligible for inclusion in order to specify the target population.

The following languages were considered for inclusion: English, German, Dutch, and Portuguese. Publications were assessed for inclusion or exclusion in 2 steps. The first selection was based on screening titles and abstracts of retrieved publications. This process was independently performed by 2 researchers (J.G.D. and G.E.). Then, full texts of remaining publications were screened. Disagreement about inclusion or exclusion of a study was resolved by consensus. Data extraction for included studies was performed independently by 2 researchers (G.E. and A.L.F./B.v.M./E.J.A.S.). A flowchart of the inclusion process can be found in Supplementary Appendix II.

The Mixed Methods Appraisal Tool (MMAT) was used as an instrument to assess methodological quality of included studies. ${ }^{42}$ Total rating scores are descriptive of quality of the study and may vary from 0 to $100 \%$. The ratings on the MMAT are included in Table 1 and are added in the text as * for $25 \%$, ${ }^{* *}$ for $50 \%$, ${ }^{* * *}$ for $75 \%$, and ${ }^{* * * *}$ for $100 \%$. Higher percentages indicate better methodological quality. This was determined by 4 criteria: presence of selection bias in the sample, validity of measurements, correction for cofounders in the analysis, and integrity of outcome data. Criteria were assessed by dichotomous answer possibility, with each "yes" adding another $25 \%$ to the score. MMAT assessment was performed independently by 2 researchers (G.E. and A.L.F./B.v.M.). Disagreement on the score of the MMAT was resolved by discussion. 
Engels, G., Francke, A.L., Meijel, B. van, Douma, J.G., Kam, H. de, Wesselink, W., Houtjes, W., Scherder, E.J.A. Clinical pain in schizophrenia: a systematic review. Journal of Pain: 2014, 15(5), 457-467

\section{[TABLE 1. ]}

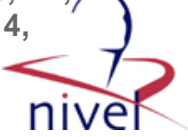

\section{RESULTS}

A total of 14 studies met our inclusion criteria. All studies, their characteristics, and relevant findings are listed in Table 1. MMAT results show that 2 studies scored 25\% on methodological criteria, ${ }^{18_{*}, 48_{*}} 4$ studies scored $50 \%,{ }^{4 *,}, 15_{* *}, 26_{* *}, 50_{* *} 6$ studies scored $75 \%,{ }^{10_{* \star *}, 12_{* \star \star}, 30_{* \star *}, 31_{* \star *}, 46_{* \star *}, 49_{* \star \star}}$ and 2 studies met all criteria for methodological quality. ${ }^{1_{* \star \star *}, 7_{* \star \star \star *}}$

\section{Prevalence of Pain}

Persons With Schizophrenia Compared to Those With Other Psychiatric Disorders

In comparison with people with other psychiatric disorders-for example, endogenous depression, neurotic/mixed depression, or anxiety neuroses (see Table 1 for details regarding diagnoses)—-the percentage of people with schizophrenia indicating no pain was the highest. ${ }^{15_{* *}}$ Of note is that this study did not mention the type of pain. Similarly, compared to persons suffering from other psychiatric disorders such as hysteria (24\%) and depressive neuroses (45\%), the percentage of people with schizophrenia having chronic pain appeared to be lower $(2 \%) .{ }^{10_{* * *}}$ In this study, only subjects with "mania (affective psychosis)" or "drug dependence" as a diagnosis had a lower prevalence of chronic pain than people with schizophrenia. The authors identified chronic pain as pain with a duration of at least 6 months. In both studies, the type of pain was not further specified. When pain was examined regardless of duration, $37.2 \%$ of a group of people with schizophrenia had pain complaints. ${ }^{50_{* *}}$ When the affected part of the body was examined in this group, the head was the most reported site of pain (39.4\%), and pain lasted longer than 6 months for more than half of the participants. Although no statistical comparisons were made between the studied group with schizophrenia and other psychiatric disorders, the authors confirmed a lower prevalence of pain complaints in people with schizophrenia than in people with other types of psychiatric illnesses. ${ }^{50_{* *}}$

In only 1 study with different psychiatric populations, a specific type of pain, that is, menstrual pain —in particular headache-was examined. ${ }^{12_{\star \star \star}}$ Again, the percentage of women with schizophrenia who did not suffer from a headache (56.4\%) was higher than women with neurosis (41.7\%), but somewhat lower than those with affective disorders (60.0\%). Unfortunately, data analyses did not focus on the comparison between the psychiatric populations but on each psychiatric group in comparison to a control group (see next section).

In sum, these 4 studies suggest that pain is less prevalent in people with schizophrenia when compared to people with other psychiatric diseases. 
Engels, G., Francke, A.L., Meijel, B. van, Douma, J.G., Kam, H. de, Wesselink, W., Houtjes, W., Scherder, E.J.A. Clinical pain in schizophrenia: a systematic review. Journal of Pain: 2014, 15(5), 457-467

\section{People With Schizophrenia Compared to Controls}

Compared to the general population, people with schizophrenia showed the same

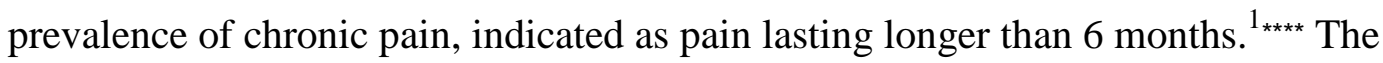
most frequent locations of pain were the abdomen, head and face region, and lower part of the spinal cord. In line with this finding, in participants with and without schizophrenia, both the absence of headache (56.4\% and $56.1 \%$, respectively ${ }^{12_{* * \star}}$ ) and the presence of headache $\left(48.1 \%\right.$ and $41 \%$, respectively $\left.{ }^{31_{* * *}}\right)$ was similar, and irrespective of its type, for example, migraine. ${ }^{31_{* \star *}}$ However, a lower prevalence of certain types of pain (eg, arthritis) has been found in veterans with schizophrenia when compared to controls without schizophrenia. In that study, a higher prevalence of other types of pain (eg, headache) has been observed. ${ }^{7_{* \star \star \star}}$ Headache after a lumbar puncture occurred much less in patients with schizophrenia, compared to controls, ${ }^{4_{* \star}}$ for example, $6 \%$ and $31 \%$, respectively, ${ }^{48_{\star}}$ and $4.7 \%$ and $25 \%$, respectively. ${ }^{18_{\star}} \mathrm{A}$ lower prevalence of pain has also been observed in people with schizophrenia who were suffering from a heart condition. ${ }^{26_{* *}}$ In that study, myocardial infarction and coronary occlusion without pain occurred in $60 \%$ of people with schizophrenia, compared to a general population in which the prevalence of a painless presentation of these heart conditions was much lower (range 0-61\%).

Taken together, it appears that prevalence of pain resulting from an apparent medical cause (eg, lumbar puncture or myocardial infarction) is lower in people with schizophrenia compared to controls. For pain without an apparent medical cause, the studies suggest that prevalence of pain is comparable to controls.

\section{Intensity of Pain}

\section{People With Schizophrenia Compared to Those With Other Psychiatric Disorders}

A survey $(\mathrm{n}=1,072,477)$ among nursing home residents suffering from various psychiatric disorders demonstrates that people with obsessive-compulsive disorder showed the highest pain intensity and people with schizophrenia and bipolar disease the lowest. ${ }^{49_{* * *}}$ According to the authors, a possible explanation is pain apathy, caused by alterations in mood and sensory processing. When intensity and pain characteristics in a group of persons with schizophrenia were addressed, $25 \%$ of the participants had severe pain intensity, 50\% had moderate pain intensity, and 25\% had mild pain intensity. ${ }^{50_{* \star}}$ For subjects participating in these 2 studies, no apparent medical cause for their pain was noted. When pain after a lumbar puncture was examined, severity of headaches was lower in subjects with schizophrenia than in subjects with affective disorders. ${ }^{4_{* *}}$ 
Engels, G., Francke, A.L., Meijel, B. van, Douma, J.G., Kam, H. de, Wesselink, W., Houtjes, W., Scherder, E.J.A. Clinical pain in schizophrenia: a systematic review. Journal of Pain: 2014, 15(5), 457-467

In sum, the findings suggest that people with schizophrenia compared to other psychiatric disorders may experience a lower intensity of pain, irrespective of the cause.

\section{People With Schizophrenia Compared to Controls}

Pain was assessed at 2 and 5 hours after an operation in persons with schizophrenia and controls. ${ }^{30_{* * *}}$ The findings showed that at both moments of measurement, pain intensity, as assessed by a visual analog scale, was significantly lower in persons with schizophrenia than the control group. The lower pain intensity was also reflected in a lower use of the analgesic pentazocine. ${ }^{30_{* \star *}}$ In the 1 person with schizophrenia experiencing headache after lumbar puncture, no analgesic treatment was required. In contrast, pain relief was necessary for almost all subjects from the control group who suffered from severe post-lumbar puncture headache. ${ }^{18_{*}}$

In contrast to the above-mentioned findings, when headache in schizophrenia was investigated regardless of etiology, this type of pain was of equal intensity in persons with and without schizophrenia. ${ }^{31_{* \star \star}}$ Another study found that the score on the subscale Bodily Pain of the Medical Outcomes Study 36-Item Short Form, assessing pain intensity, was one of the best predictors for being a person with schizophrenia, instead of being a person belonging to the control group. ${ }^{46_{* * \star}}$ It must be noted that this score did not significantly differ per group in this study.

In summary, it appears that the intensity of pain is lower in people with schizophrenia compared to healthy controls in situations that involve an apparent medical cause. No difference appears to exist between subjects with schizophrenia and controls for pain (eg, headache) without such a cause.

\section{DISCUSSION}

\section{Prevalence of Pain}

Our findings suggest that people with schizophrenia have a lower prevalence of pain compared to people with other psychiatric disorders. Although none of the studies included people with somatoform disorders, where pain is an actual symptom of the disorder, it should be noted that 1 study did report on psychogenic pain in people with schizophrenia compared to controls. In that study, prevalence of pain was higher.7**** When compared to controls, pain appears to be less prevalent in people with schizophrenia when it regards apparent medical conditions (eg, myocardial infarction, lumbar puncture). This difference was not found for pain without such an apparent cause.

\section{Intensity of Pain}


Engels, G., Francke, A.L., Meijel, B. van, Douma, J.G., Kam, H. de, Wesselink, W., Houtjes, W., Scherder, E.J.A. Clinical pain in schizophrenia: a systematic review. Journal of Pain: 2014, 15(5), 457-467

When compared to people with a psychiatric disorder, people with schizophrenia appear to have a lower intensity of pain. When people with schizophrenia were compared with control subjects without a psychiatric disorder, intensity of pain was lower for people with schizophrenia when it concerned situations in which pain was the result of an apparent medical cause. Again, when the pain was not related to a medical situation (eg, lumbar puncture), a difference appeared to be absent.

\section{A Possible Explanation for a Decrease of Pain in Persons With Schizophrenia}

A possible explanation for the finding of a decrease in pain in people with schizophrenia emerges from the study of Kuritzky and colleagues. ${ }^{31_{* \star \star}}$ They observed that a large percentage of people with schizophrenia (40\%) who indicated that they had a pain complaint had never before reported this complaint. According to these authors, people refrain from complaining about pain in order to avoid being a burden and to avoid hospitalization. ${ }^{31_{* * *}}$ We argue that particularly these reasons might explain why people with schizophrenia might also complain less of pain in case of, for example, an operation, lumbar puncture, or myocardial infarction.

The question arises whether a decrease in complaining about pain also means that persons with schizophrenia experience less pain. A decrease in pain experience might be due to the deviant processing of the motivational-affective aspect of pain. ${ }^{34}$ It has been suggested that the processing of motivational-affective aspects of pain requires an intact neuronal circuit connecting the limbic system and the frontal lobe. ${ }^{35}$ A decline in the processing of the motivational-affective pain aspects might therefore be due to a dysfunction of the frontal lobe in schizophrenia. ${ }^{18_{*}}$ It is known that the frontal lobe, in particular the prefrontal cortex, plays a role in processing motivational-affective aspects of pain. ${ }^{35}$

Indeed, from all persons with schizophrenia who complained of headache, not everybody said to experience pain as well (84.6\%). ${ }^{31_{* * *}}$ We argue that this might be due to a deviant processing of the motivational-affective aspects of pain. This difference between experiencing pain (or pain perception) and pain behavior (or pain expression) is clinically relevant: A person might experience pain but not necessarily behave accordingly. ${ }^{34}$

Next to a neuropathological point of view, as described above, firm conclusions about people with schizophrenia being less sensitive or reactive to pain as an explanation for reduced pain experience in schizophrenia cannot be drawn-either from a physiological point of view (for example, an increased pain threshold and tolerance) ${ }^{24}$ or from a biochemical point of view (for example, high activity of central endorphins). ${ }^{9}$ Bonnot and coworkers stipulate that an increased response to pain such as atypical pain has also been observed in persons with schizophrenia. It has been suggested that people with schizophrenia may show an alteration in pain experience because of a decline in among others cognitive functions. ${ }^{9}$ and 27 
Engels, G., Francke, A.L., Meijel, B. van, Douma, J.G., Kam, H. de, Wesselink, W., Houtjes, W., Scherder, E.J.A. Clinical pain in schizophrenia: a systematic review. Journal of Pain: 2014, 15(5), 457-467

A final explanation for a reduced pain experience in persons with schizophrenia might be the use of antipsychotics. Antipsychotics have been shown to have analgesic efficacy. ${ }^{47}$ However, in a meta-analysis investigating experimental pain in schizophrenia, this analgesic effect was found not to explain the observed diminished pain response in persons with schizophrenia. ${ }^{43}$ In one of the included studies, postoperative scores on a visual analog scale also appeared not to be influenced by antipsychotics. ${ }^{30_{* \star *}}$ Antipsychotic medication might also be beneficial for cognition, ${ }^{29}$ subsequently influencing pain, although the positive effect of antipsychotics on cognition has not consistently been found. ${ }^{23}$

\section{Limitations and Suggestions for Future Studies}

Several limitations should be taken into account. First, it must be noted that schizophrenia is a complex psychopathological disorder, with heterogeneity in symptoms: Two persons may display a completely different set of symptoms and yet both be diagnosed with schizophrenia. Negative symptoms of schizophrenia, such as avolition and affective flattening, have been put forward as a reason for refraining from complaints about pain to, for example, a physician, ${ }^{7 * \star \star}, 16$ although people are indeed capable of precise description of pain. ${ }^{31_{* \star \star}}$ Whether persons display mostly negative or positive symptoms might already partly determine pain outcomes. Second, conclusions about an alteration in pain experience in schizophrenia in the present study might be weakened by the fact that criteria for the diagnosis of schizophrenia have changed over time, and a number of studies were conducted decades ago. Third, our MMAT quality assessment indicates that not every included study was of optimal methodological quality, which might bias our conclusions. Fourth, the method of pain assessment might partly determine the outcome of the studies. For example, presence of pain (sensory-discriminative aspect) might be different from experience of pain (motivational-affective aspect), as mentioned before. $^{31_{* * *}}$ Therefore, future studies should not only assess presence of pain, but also inquire about intensity and other aspects of pain, as well as type of pain (eg, chronic or acute pain). ${ }^{7_{* * * *}, 12_{* * *}, 30_{* * *}, 31_{* * *}}$

In order to achieve a comprehensive assessment of pain, instruments should be chosen carefully. For example, the McGill Pain Questionnaire is developed to inquire about sensory-discriminative as well as motivational-affective and cognitiveevaluative aspects of pain. ${ }^{39}$ Not only should the aspect of pain guide the choice of the instrument, but comprehension of pain rating scales also should be taken into account. For example, understanding facial expressions that represent pain is found to be impaired in schizophrenia. ${ }^{36}$ This makes use of the Faces Pain Scale less suitable for this group.

In conclusion, lack of awareness of possible alterations in pain in schizophrenia might result in an undertreatment of pain, particularly concerning the motivationalaffective aspect, because this aspect plays an important role in the decision to ask for medical help. ${ }^{45}$ Together with the fact that prevalence of painful physical illnesses 
Engels, G., Francke, A.L., Meijel, B. van, Douma, J.G., Kam, H. de, Wesselink, W., Houtjes, W., Scherder, E.J.A. Clinical pain in schizophrenia: a systematic review. Journal of Pain: 2014, 15(5), 457-467

(eg, hepatitis, osteoporosis, cardiovascular disease, and dental problems) is increased in schizophrenia, ${ }^{33}$ knowledge about pain in schizophrenia is needed to treat people adequately.

\section{REFERENCES}

1 J.G. Almeida, G.P. Kurita, P.E. Braga, C.A.M. Pimenta Dor crônica em pacientes esquizofrênicos: Prevalência e características; Chronic pain in schizophrenic patients: prevalence and characteristics Cad saúde pública, 26 (2010), pp. 591-602

2 American Psychiatric Association, APA Task Force on APA DSM-IV Diagnostic and Statistical Manual of Mental Disorders: DSM-IV-TR American Psychiatric Publishing, Inc, Washington, DC (2000)

3 L. Atik, N. Konuk, O. Akay, D. Ozturk, A. Erdogan Pain perception in patients with bipolar disorder and schizophrenia Acta Neuropsychiatrica, 19 (2007), pp. 284-290

4 J.C. Ballenger, R.M. Post, D.E. Sternberg, D.P. Van Kammen, R.W. Cowdry, F.K. Goodwin Headaches after lumbar puncture and insensitivity to pain in psychiatric patients N Engl J Med, 301 (1979), p. 110

5 K.J. Bär, S. Brehm, M.K. Boettger, S. Boettger, G. Wagner, H. Sauer Pain perception in major depression depends on pain modality Pain, 117 (2005), pp. 97-103

6 L.K. Bickerstaff, S.C. Harris, R.S. Leggett, K.C. Cheah Pain insensitivity in schizophrenic patients. A surgical dilemma Arch Surg, 123 (1988), pp. 49-51

7 D.G. Birgenheir, M.A. Ilgen, A.S. Bohnert, K.M. Abraham, N.W. Bowersox, K. Austin, A.M. Kilbourne Pain conditions among veterans with schizophrenia or bipolar disorder Gen Hosp Psychiatry, 35 (2013), pp. 480-484

8 R. Blumensohn, D. Ringler, I. Eli Pain perception in patients with schizophrenia J Nerv Ment Dis, 190 (2002), pp. 481-483

9 O. Bonnot, G.M. Anderson, D. Cohen, J.C. Willer, S. Tordjman Are patients with schizophrenia insensitive to pain? A reconsideration of the question Clin J Pain, 25 (2009), pp. 244-252

10 S.K. Chaturvedi Prevalence of chronic pain in psychiatric patients Pain, 29 (1987), pp. 231-237

11 L. Collins, L.A. Stone Pain sensitivity, age and activity level in chronic schizophrenics and in normal Br J Psychiatry, 112 (1966), pp. 33-

$12 \mathrm{~A}$. Coppen The prevalence of menstrual disorders in psychiatric patients Br J Psychiatry, 111 (1965), pp. 155-167

13 C. de la Fuente-Sandoval, R. Favila, D. Gomez-Martin, F. Pellicer, A. Graff-Guerrero Functional magnetic resonance imaging response to experimental pain in drug-free patients with schizophrenia Psychiatry Res, 183 (2010), pp. 99-104

14 C. de la Fuente-Sandoval, R. Favila, D. Gomez-Martin, P. Leon-Ortiz, A. Graff-Guerrero Neural response to experimental heat pain in stable patients with schizophrenia J Psychiatr Res, 46 (2011), pp. 128-134

15 R. Delaplaine, O. Ifabumuyi, H. Merskey, J. Zarfas Significance of pain in psychiatric hospital patients Pain, 4 (1978), pp. 361-366

16 R.H. Dworkin, W. Clark, J.D. Lipsitz, X.F. Amador, C.A. Kaufmann, L.A. Opler, S.R. White, J.M. Gorman Affective deficits and pain insensitivity in schizophrenia Motiv Emot, 17 (1993), pp. 245-276

17 R.R. Edwards, J.A. Haythornthwaite, M.J. Sullivan, R.B. Fillingim Catastrophizing as a mediator of sex differences in pain: Differential effects for daily pain versus laboratoryinduced pain Pain, 111 (2004), pp. 335-341 
Engels, G., Francke, A.L., Meijel, B. van, Douma, J.G., Kam, H. de, Wesselink, W., Houtjes, W., Scherder, E.J.A. Clinical pain in schizophrenia: a systematic review. Journal of Pain: 2014, 15(5), 457-467

18 R.S. El-Mallakh, D. Garver, J.A. Holcomb, R.J. Wyatt Post lumbar-puncture headaches in schizophrenic and psychiatrically normal control subjects Schizophr Res, 77 (2005), pp.

111-112

19 R.B. Fillingim, R.R. Edwards, T. Powell The relationship of sex and clinical pain to experimental pain responses Pain, 83 (1999), pp. 419-425

20 D.A. Fishbain Pain insensitivity in psychosis Ann Emerg Med, 11 (1982), pp. 630-632

21 N. Geschwind Insensitivity to pain in psychotic patients N Engl J Med, 296 (1977), p. 1480

22 M. Girard, B. Plansont, H. Bonnabau, D. Malauzat Experimental pain hypersensitivity in schizophrenic patients Clin J Pain, 27 (2011), pp. 790-795

23 T.E. Goldberg, R.S. Goldman, K.E. Burdick, A.K. Malhotra, T. Lencz, R.C. Patel, M.G. Woerner, N.R. Schooler, J.M. Kane, D.G. Robinson Cognitive improvement after treatment with second-generation antipsychotic medications in first-episode schizophrenia: Is it a practice effect? Arch Gen Psychiatry, 64 (2007), p. 1115

24 R. Guieu, J.C. Samuelian, H. Coulouvrat Objective evaluation of pain perception in patients with schizophrenia Br J Psychiatry, 164 (1994), pp. 253-255

25 P.J. Harrison Neuropathology of schizophrenia Psychiatry, 7 (2008), pp. 421-424

26 A.E. Hussar Coronary heart disease in chronic schizophrenic patients: A clinicopathologic study Circulation, 31 (1965), pp. 919-929

27 T. Jochum, A. Letzsch, W. Greiner, G. Wagner, H. Sauer, K.J. Bar Influence of antipsychotic medication on pain perception in schizophrenia Psychiatry Res, 142 (2006), pp. 151-156

28 M. Karst, N. Rahe-Meyer, A. Gueduek, L. Hoy, M. Borsutzky, T. Passie Abnormality in the self-monitoring mechanism in patients with fibromyalgia and somatoform pain disorder

Psychosom Med, 67 (2005), pp. 111-115

29 R.S. Keefe, R.M. Bilder, S.M. Davis, P.D. Harvey, B.W. Palmer, J.M. Gold, H.Y. Meltzer, M.F. Green, G. Capuano, T.S. Stroup Neurocognitive effects of antipsychotic medications in patients with chronic schizophrenia in the CATIE Trial Arch Gen Psychiatry, 64 (2007), p. 633

$30 \mathrm{~A}$. Kudoh, H. Ishihara, A. Matsuki Current perception thresholds and postoperative pain in schizophrenic patients Reg Anesth Pain Med, 25 (2000), pp. 475-479

31 A. Kuritzky, D. Mazeh, A. Levi Headache in schizophrenic patients: A controlled study Cephalalgia, 19 (1999), pp. 725-727

32 S. Lautenbacher, G.B. Rollman, G. McCain Multi-method assessment of experimental and clinical pain in patients with fibromyalgia Pain, 59 (1994), pp. 45-53

33 S. Leucht, T. Burkard, J. Henderson, M. Maj, N. Sartorius Physical illness and schizophrenia: A review of the literature Acta Psychiatr Scand, 116 (2007), pp. 317-333

34 J.D. Loeser, R. Melzack Pain: An overview Lancet, 353 (1999), pp. 1607-1609

$35 \mathrm{H}$. Maeoka, A. Matsuo, M. Hiyamizu, S. Morioka, H. Ando Influence of transcranial direct current stimulation of the dorsolateral prefrontal cortex on pain related emotions: A study using electroencephalographic power spectrum analysis Neurosci Lett, 512 (2012), pp. 1216

36 M.J. Martins, B.L. Moura, I.P. Martins, M.L. Figueira, K.M. Prkachin Sensitivity to expressions of pain in schizophrenia patients Psychiatry Res, 189 (2011), pp. 180-184

37 J. McGrath, S. Saha, D. Chant, J. Welham Schizophrenia: A concise overview of incidence, prevalence, and mortality Epidemiol Rev, 30 (2008), pp. 67-76

38 R. Melzack, K.L. Casey Sensory, motivational and central control determinants of pain: A new conceptual model D.R. Kenshalo (Ed.), The Skin Senses, Charles C. Thomas,

Springfield, IL (1968), pp. 423-443 
Engels, G., Francke, A.L., Meijel, B. van, Douma, J.G., Kam, H. de, Wesselink, W., Houtjes, W., Scherder, E.J.A. Clinical pain in schizophrenia: a systematic review. Journal of Pain: 2014, 15(5), 457-467

39 R. Melzack The McGill Pain Questionnaire: Major properties and scoring methods Pain, 1 (1975), pp. 277-299

40 H. Murakami, N. Tamasawa, T. Suda Diminished pain perception in schizophreniaAuthors' reply Lancet, 376 (2010), pp. 87-88

41 B.V.S. Murthy, B. Narayan, S. Nayagam Reduced perception of pain in schizophrenia: Its relevance to the clinical diagnosis of compartment syndrome Injury, 35 (2004), pp. 1192 1193

42 Pluye P, Robert E, Cargo M, Bartlett G, C'Cathain A, Griffiths F, Boardman F, Gagnon MP, Rousseau MC: Proposal: A mixed methods appraisal tool for systematic mixed studies reviews; 2011. Available from http://mixedmethodsappraisaltoolpublic.pbworks.com. Archived by WebCite ${ }^{\circledR}$ at http://www.webcitation.org/5tTRTc9yJ. Accessed January 2014

43 S. Potvin, S. Marchand Hypoalgesia in schizophrenia is independent of antipsychotic drugs: A systematic quantitative review of experimental studies Pain, 138 (2008), pp. 7078

44 S.H. Rosenthal, K.A. Porter, B. Coffey Pain insensitivity in schizophrenia. Case report and review of the literature Gen Hosp Psychiatry, 12 (1990), pp. 319-322

45 E.J.A. Scherder, J.A. Sergeant, D.F. Swaab Pain processing in dementia and its relation to neuropathology Lancet Neurol, 2 (2003), pp. 677-686

46 A. Sciolla, T.L. Patterson, J.L. Wetherell, L.A. McAdams, D.V. Jeste Functioning and wellbeing of middle-aged and older patients with schizophrenia: Measurement with the 36-item short-form (SF-36) health survey Am J Geriatr Psychiatry, 11 (2003), pp. 629-637

47 S. Seidel, M. Aigner, M. Ossege, E. Pernicka, B. Wildner, T. Sycha Antipsychotics for acute and chronic pain in adults J Pain Symptom Manage, 39 (2010), pp. 768-778

48 E.F. Torrey Headaches after lumbar puncture and insensitivity to pain in psychiatric patients N Engl J Med, 301 (1979), p. 110

49 M.S. Walid, N. Zaytseva Pain in nursing home residents and correlation with neuropsychiatric disorders Pain Physician, 12 (2009), pp. 877-880

$50 \mathrm{G}$. Watson, P. Chandarana, H. Merskey Relationships between pain and schizophrenia Br J Psychiatry, 138 (1981), pp. 33-36 
Table 1. Overview of Included Studies Assessing Clinical Pain in Schizophrenia

\begin{tabular}{|c|c|c|c|c|c|c|c|}
\hline STUDY & $\begin{array}{l}\text { MMAT } \\
\text { SCORE }\end{array}$ & Study Design & $\begin{array}{c}\text { SUBUECT } \\
\text { CHARACTERISTICS }\end{array}$ & $\begin{array}{c}\text { Detalls } \\
\text { Diagnosis }\end{array}$ & $\begin{array}{l}\text { OUTCOME } \\
\text { VARIABLEE }\end{array}$ & Мethods & RESULTS \\
\hline Delaplaine et al, $1978^{15 * *}$ & $50 \%$ & Cross-sectional & 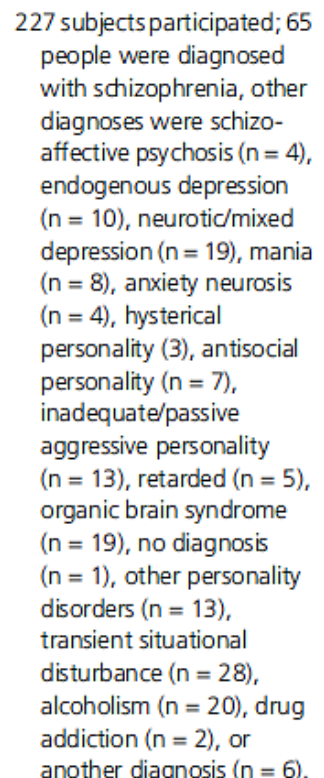 & Schizophrenia & $\begin{array}{l}\text { Presence, site and severity of } \\
\text { pain (severe, moderate, } \\
\text { mild) }\end{array}$ & $\begin{array}{l}\text { Standardized survey in } \\
\text { psychiatric hospital about } \\
\text { occurrence and } \\
\text { characteristics of pain. If } \\
\text { pain was not reported } \\
\text { spontaneously, people } \\
\text { were asked about it. } \\
\text { Analyses performed were } \\
\chi^{2} \text { tests. }\end{array}$ & $\begin{array}{l}\text { Pain was less common in } \\
\text { schizophrenia compared } \\
\text { to the other psychiatric } \\
\text { disorders under study. }\end{array}$ \\
\hline Chaturvedi, $1987^{10_{\star \star \star}}$ & $75 \%$ & Cross-sectional & $\begin{array}{l}500 \text { consecutive psychiatric } \\
\text { patients: schizophrenia } \\
(n=110) \text {, affective } \\
\text { psychosis }(n=87) \text {, anxiety } \\
\text { states }(n=40) \text {, depressive } \\
\text { neurosis }(n=100) \text {, } \\
\text { hysteria }(n=37) \text {, "other } \\
\text { neurosis" }(n=15) \text {, drug } \\
\text { dependence }(n=27) \text {, and } \\
\text { "others" }(n=84) \text {. }\end{array}$ & $\begin{array}{l}\text { Diagnosis of schizophrenia in } \\
\text { consultation with } \\
\text { psychiatrist }\end{array}$ & $\begin{array}{l}\text { Presence of chronic pain (ie, } \\
\text { daily pain/pain once every } \\
2 \mathrm{~d} \text {, lasting longer than } \\
6 \mathrm{mo} \text { ) }\end{array}$ & $\begin{array}{l}\text { Chronic pain was } \\
\text { determined by patients' } \\
\text { reports. Relatives provided } \\
\text { additional information. }\end{array}$ & $\begin{array}{l}1.8 \% \text { of people with } \\
\text { schizophrenia had chronic } \\
\text { pain, compared to an } \\
\text { average of } 18.6 \% \text { of all } \\
\text { psychiatric patients (no } P \\
\text { values provided). }\end{array}$ \\
\hline
\end{tabular}


Table 1. Continued

\begin{tabular}{|c|c|c|c|c|c|c|c|}
\hline StudY & $\begin{array}{c}\text { MMAT } \\
\text { SCORE }\end{array}$ & Study DESIGN & $\begin{array}{c}\text { SUBJECT } \\
\text { CHARACTERISTICS }\end{array}$ & $\begin{array}{c}\text { Detalls } \\
\text { Diagnosis }\end{array}$ & $\begin{array}{l}\text { OUTCOME } \\
\text { VARIABLE }\end{array}$ & Methods & REsults \\
\hline Watson, $1981^{50 * *}$ & $50 \%$ & Cross-sectional & $\begin{array}{l}78 \text { subjects ( } 46 \text { men, mean } \\
\text { age } 30.3 ; 32 \text { women, } \\
\text { mean age } 37.4 \text { ) } \\
\text { diagnosed with } \\
\text { schizophrenia }\end{array}$ & $\begin{array}{l}\text { Diagnosis was based on } \\
\text { "appropriate changes of } \\
\text { thought, volition and } \\
\text { affect, and evidence at } \\
\text { some point during the } \\
\text { illness of the presence of } \\
\text { first rank symptoms of } \\
\text { Schneider in the absence } \\
\text { of coarse organic brain } \\
\text { disease." }\end{array}$ & $\begin{array}{l}\text { A verbal description } \\
\text { (interview) concerning } \\
\text { pain and pain } \\
\text { characteristics }\end{array}$ & $\begin{array}{l}\text { Examination of pain } \\
\text { characteristics (duration, } \\
\text { location, and intensity) } \\
\text { and descriptions }\end{array}$ & $\begin{array}{l}37.2 \% \text { of subjects with } \\
\text { schizophrenia had pain } \\
\text { complaints ( } 16.7 \% \text { with } \\
\text { appropriate organic } \\
\text { cause). } 25 \% \text { showed mild } \\
\text { pain, } 50 \% \text { moderate pain, } \\
25 \% \text { had severe pain. } \\
\text { Headache was the most } \\
\text { prevalent pain complaint. }\end{array}$ \\
\hline Coppen, $1965^{12 \star \star \star}$ & $75 \%$ & Cross-sectional & $\begin{array}{l}616 \text { participants: } 151 \\
\text { women with a psychiatric } \\
\text { diagnosis (neurosis } \\
{[n=49] \text {, affective disorder }} \\
{[n=41] \text {, or schizophrenia }} \\
\text { [n=61], mean age } 35.5 y \text { ) } \\
\text { and a control group } \\
(n=465) \text {. Subjects were } \\
\text { recruited from } 3 \\
\text { psychiatric institutions } \\
\text { and their outpatient } \\
\text { departments. }\end{array}$ & $\begin{array}{l}\text { The diagnosis was derived } \\
\text { from the consultant in } \\
\text { charge. }\end{array}$ & $\begin{array}{l}\text { Severity of pain and } \\
\text { headache related to } \\
\text { menstrual period }\end{array}$ & $\begin{array}{l}3 \text { groups of women with a } \\
\text { psychiatric disorder were } \\
\text { compared to a matched } \\
\text { control group on a } \\
\text { questionnaire regarding } \\
\text { menstrual disorders } \\
\text { (among which pain and } \\
\text { headache). Questions on } \\
\text { menstrual pain and } \\
\text { headache were answered } \\
\text { on a 4-point scale (nil, } \\
\text { slight, moderate, and } \\
\text { severe). }\end{array}$ & $\begin{array}{l}\text { Women with schizophrenia } \\
\text { complained of } \\
\text { significantly less pain } \\
\text { when compared to their } \\
\text { matched controls } \\
(P<.05) \text {. }\end{array}$ \\
\hline de Almeida et al, $2010^{1 * \star \star *}$ & $100 \%$ & Cross-sectional & $\begin{array}{l}205 \text { persons with } \\
\text { schizophrenia, mean age } \\
37 \mathrm{y}\end{array}$ & $\begin{array}{l}\text { Schizophrenia (diagnosed } \\
\text { according to ICD-10 } \\
\text { criteria) }\end{array}$ & $\begin{array}{l}\text { Prevalence and quality of } \\
\text { chronic pain, that is, pain } \\
\text { lasting more than } 3 \text { mo }\end{array}$ & $\begin{array}{l}\text { Questionnaires about } \\
\text { prevalence and quality of } \\
\text { chronic pain during the } \\
\text { past week and at time of } \\
\text { interview }\end{array}$ & $\begin{array}{l}36.6 \% \text { of the subjects } \\
\text { experienced chronic pain. } \\
\text { Descriptions of pain were } \\
\text { similar to those found in } \\
\text { the McGill Pain } \\
\text { Questionnaire, indicating } \\
\text { people are capable of } \\
\text { describing their pain. }\end{array}$ \\
\hline
\end{tabular}


Table 1. Continued

\begin{tabular}{|c|c|c|c|c|c|c|c|}
\hline STUDY & $\begin{array}{c}\text { MMAT } \\
\text { SCOAE }\end{array}$ & STUDY DESIGN & $\begin{array}{c}\text { SUBJECT } \\
\text { CHARACTERISTICS } \\
\end{array}$ & $\begin{array}{c}\text { Detalls } \\
\text { Diagnosis } \\
\end{array}$ & $\begin{array}{l}\text { OUTCOME } \\
\text { VAAIABLE } \\
\end{array}$ & MEthods & RESULTS \\
\hline Kuritzky, $1999^{31 * \star \star *}$ & $75 \%$ & Case-control & $\begin{array}{l}208 \text { subjects participated: } \\
\text { persons with } \\
\text { schizophrenia }(n=108) \text {, at } \\
\text { least } 2 \text { y of treatment, } \\
\text { mean age } 35.6 \text {, and a } \\
\text { group of people without } \\
\text { schizophrenia }(n=100)\end{array}$ & $\begin{array}{l}\text { Schizophrenia as diagnosed } \\
\text { by DSM-III-R criteria, in a } \\
\text { chronic stage (ie, at least } \\
2 \text { y of treatment); control } \\
\text { subjects did not have a } \\
\text { diagnosis }\end{array}$ & $\begin{array}{l}\text { Type, location, frequency, } \\
\text { severity, duration, and } \\
\text { complaints of headache } \\
\text { were assessed by using } \\
\text { the questionnaire. }\end{array}$ & $\begin{array}{l}\text { Questionnaire about } \\
\text { characteristics of } \\
\text { headache was } \\
\text { administered. Analyses } \\
\text { were performed with a } \\
\text { Pearson } \chi^{2} \text { test. }\end{array}$ & $\begin{array}{l}\text { Prevalence, type, and } \\
\text { intensity of headache was } \\
\text { similar for controls and } \\
\text { patients ( } P=.3 \text { ). } \\
\text { Frequency was higher in } \\
\text { schizophrenia }(P=.04) \text {. A } \\
\text { significant reduction in } \\
\text { duration of headache } \\
\text { after treatment was found } \\
\text { in schizophrenia } \\
(P=.0009) \text {. Only } 84.6 \% \\
\text { who complained of } \\
\text { headache also claimed to } \\
\text { experience pain. }\end{array}$ \\
\hline Birgenheir et al, $2013^{7 * \star \star \star \star}$ & $100 \%$ & Cross-sectional & $\begin{array}{l}\text { A total of } 5,195,551 \\
\text { individuals participated. } \\
\text { Diagnoses were } \\
\text { schizophrenia/ } \\
\text { schizoaffective disorder } \\
\text { ( } \mathrm{n}=93,874), \text { bipolar } \\
\text { disorder }(\mathrm{n}=96,186) \text {, } \\
\text { depressive disorder } \\
\text { ( } \mathrm{n}=757,807) \text {, or no } \\
\text { diagnosis }(\mathrm{n}=4,247,684) \text {. }\end{array}$ & $\begin{array}{l}\text { Schizophrenia/ } \\
\text { schizoaffective disorder } \\
\text { (referred to as } \\
\text { "schizophrenia") } \\
\text { according to health care } \\
\text { providers using ICD-9-CM }\end{array}$ & $\begin{array}{l}\text { Presence of arthritis, back } \\
\text { pain, chronic noncancer } \\
\text { pain, migraine headache, } \\
\text { tension and other } \\
\text { headache, psychogenic or } \\
\text { neuropathic pain (ICD-9- } \\
\text { CM) }\end{array}$ & $\begin{array}{l}\text { Presence of pain and } \\
\text { psychiatric diagnosis } \\
\text { (derived from electronic } \\
\text { medical records) }\end{array}$ & $\begin{array}{l}\text { Compared to people } \\
\text { without schizophrenia, } \\
\text { bipolar disorder, or } \\
\text { depressive disorder, } \\
\text { people with schizophrenia } \\
\text { were more likely to have } \\
\text { chronic pain }(\mathrm{OR}=2.10) \text {, } \\
\text { migraine (OR }=1.13) \text {, or } \\
\text { other headache } \\
(\mathrm{OR}=1.46) \text { and } \\
\text { psychogenic pain } \\
\text { conditions (OR }=2.72) \text {. } \\
\text { Adversely, arthritis } \\
(\mathrm{OR}=.93 \text { ) and } \\
\text { neuropathic pain } \\
\text { (OR }=.94 \text { ) were less likely } \\
\text { to occur in schizophrenia. }\end{array}$ \\
\hline
\end{tabular}




\begin{tabular}{|c|c|c|c|c|c|c|c|}
\hline StudY & $\begin{array}{l}\text { MMAT } \\
\text { SCORE }\end{array}$ & StUdY DESIGN & $\begin{array}{c}\text { SUBJECT } \\
\text { CHARACTERISTICS }\end{array}$ & $\begin{array}{c}\text { Detalls } \\
\text { DIAGNosis }\end{array}$ & $\begin{array}{l}\text { OUTCOME } \\
\text { VARIABLE }\end{array}$ & Methods & Results \\
\hline Ballenger, $1979^{4 * \star}$ & $50 \%$ & Case-control study & $\begin{array}{l}74 \text { persons diagnosed with } \\
\text { schizophrenia undergoing } \\
\text { lumbar puncture }\end{array}$ & Schizophrenia & $\begin{array}{l}\text { Presence, intensity, and } \\
\text { duration of headache } \\
\text { after lumbar puncture }\end{array}$ & $\begin{array}{l}\text { Headache was examined } \\
\text { after lumbar puncture. } \\
\text { Analyses were performed } \\
\text { with } \chi^{2} \text {-test. }\end{array}$ & $\begin{array}{l}\text { Compared to healthy } \\
\text { controls, prevalence of } \\
\text { headache was lower } \\
(P<.05) \text { and duration was } \\
\text { shorter }(P<.05) . \\
\text { Compared to people with } \\
\text { affective illness, } \\
\text { headaches occurred as } \\
\text { often but with a shorter } \\
\text { duration }(P<.01) \text { and less } \\
\text { severely }(P<.05) \text {. }\end{array}$ \\
\hline Torrey, $1979^{48 *}$ & $25 \%$ & Case-control study & $\begin{array}{l}126 \text { subjects, } 100 \text { persons } \\
\text { who were diagnosed with } \\
\text { schizophrenia and } \\
\text { underwent lumbar } \\
\text { puncture, } 26 \text { controls } \\
\text { without schizophrenia }\end{array}$ & Schizophrenia & $\begin{array}{l}\text { Presence and duration of } \\
\text { headache after lumbar } \\
\text { puncture }\end{array}$ & $\begin{array}{l}\text { Headache was examined } \\
\text { after lumbar puncture. No } \\
P \text { values are provided. }\end{array}$ & $\begin{array}{l}\text { Subjects with schizophrenia } \\
\text { experienced less } \\
\text { headaches than controls: } \\
6 \% \text { of subjects with } \\
\text { schizophrenia and } 69 \% \\
\text { control subjects had } \\
\text { headaches. }\end{array}$ \\
\hline Hussar, $1965^{26 * *}$ & $50 \%$ & Cross-sectional & $\begin{array}{l}123 \text { persons with } \\
\text { schizophrenia who } \\
\text { experienced myocardial } \\
\text { infarction or coronary } \\
\text { occlusion. All subjects } \\
\text { were male and older than } \\
\text { age } 40 \mathrm{y} \text {. }\end{array}$ & $\begin{array}{l}\text { Chronic schizophrenia } \\
\text { (mean duration } 24 \text { y) }\end{array}$ & $\begin{array}{l}\text { Presence of painless } \\
\text { myocardial infarction, as } \\
\text { described in clinical report }\end{array}$ & $\begin{array}{l}\text { Of } 343 \text { subjects with } \\
\text { schizophrenia, } 220 \text { died of } \\
\text { myocardial infarction/ } \\
\text { coronary occlusion; } 123 \\
\text { subjects survived. The } \\
\text { clinical reports of these } \\
123 \text { subjects were } \\
\text { examined postmortem. } \\
\text { Descriptive statistics were } \\
\text { presented. No } P \text { values } \\
\text { were provided. }\end{array}$ & $\begin{array}{l}60 \% \text { of the } 123 \text { patients } \\
\text { with schizophrenia } \\
\text { experienced no pain in } \\
\text { chest or surrounding areas } \\
\text { in a myocardial infarction } \\
\text { or coronary occlusion. }\end{array}$ \\
\hline
\end{tabular}

puncture, 26 controls

subjects participated:21 subjects with

schizophrenia (age rang 22-50y) and 20 healthy

controls

xperienced myocardia

farction or coronary

re male and older

ge $40 \mathrm{y}$ 
Table 1. Continued

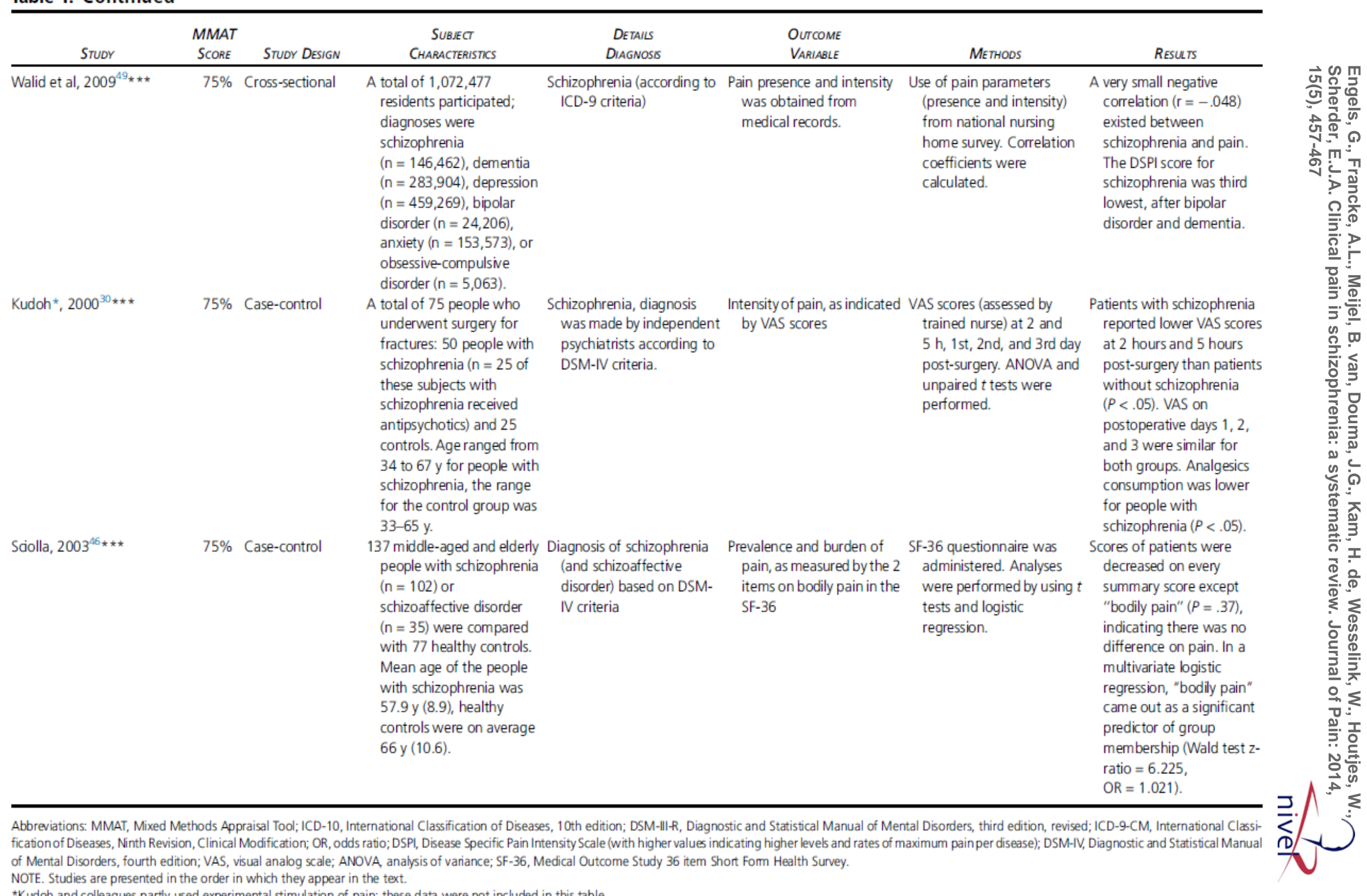

*Kudoh and colleagues partly used experimental stimulation of pain; these data were not included in this table 
PubMed:

\section{\#1 Schizophrenia}

"Schizophrenia and Disorders with Psychotic Features"[Mesh] OR "Schizoid Personality Disorder"[Mesh] OR "Schizotypal Personality Disorder"[Mesh] OR Schizophreni*[tiab] OR "Dementia Praecox"[tiab] OR "Dementia Precox"[tiab]

\section{\#2 Pain}

"Pain"[Mesh] OR pain*[tiab] OR ache*[tiab] OR "Pain Threshold"[Mesh] OR "Pain Measurement"[Mesh] OR "Hyperalgesia"[Mesh] OR hyperalgesi*[tiab] OR allodynia*[tiab] OR "Analgesia"[Mesh] OR analgesi*[tiab] OR "Pain Perception"[Mesh] OR "Nociception"[tiab]

\section{\#3 Filter: Adults}

NOT (("Adolescent"[Mesh] OR "Child"[Mesh] OR "Infant"[Mesh] OR adolescen*[tiab] OR child*[tiab] OR schoolchild*[tiab] OR infant*[tiab] OR girl*[tiab] OR boy*[tiab] OR teen[tiab] OR teens[tiab] OR teenager*[tiab] OR youth*[tiab] OR pediatr*[tiab] OR paediatr*[tiab] OR puber*[tiab]) NOT ("Adult"[Mesh] OR adult*[tiab] OR man[tiab] OR men[tiab] OR woman[tiab] OR women[tiab]))

\section{\#5 Publication types filter/animals:}

NOT ("addresses"[Publication Type] OR "biography"[Publication Type] OR "comment"[Publication Type] OR "directory"[Publication Type] OR "editorial"[Publication Type] OR "festschrift"[Publication Type] OR "interview"[Publication Type] OR "lectures"[Publication Type] OR "legal cases"[Publication Type] OR "legislation"[Publication Type] OR "letter"[Publication Type] OR "news"[Publication Type] OR "newspaper article"[Publication Type] OR "patient education handout"[Publication Type] OR "popular works"[Publication Type] OR "congresses"[Publication Type] OR "consensus development conference"[Publication Type] OR "consensus development conference, nih"[Publication Type]) NOT (animals[mh] NOT humans[mh])

\begin{tabular}{|c|c|c|}
\hline Search & PubMed & $\begin{array}{l}\text { Items } \\
\text { found }\end{array}$ \\
\hline$\# 42$ & $\begin{array}{l}\text { Search \#41 NOT (("Adolescent"[Mesh] OR "Child"[Mesh] OR "Infant"[Mesh] OR adolescen*[tiab] OR child*[tiab] } \\
\text { OR schoolchild*[tiab] OR infant*[tiab] OR girl*[tiab] OR boy*[tiab] OR teen[tiab] OR teens[tiab] OR } \\
\text { teenager*[tiab] OR youth*[tiab] OR pediatr*[tiab] OR paediatr*[tiab] OR puber*[tiab]) NOT ("Adult"[Mesh] OR } \\
\text { adult*[tiab] OR man[tiab] OR men[tiab] OR woman[tiab] OR women[tiab])) }\end{array}$ & $\underline{1222}$ \\
\hline$\# 41$ & $\begin{array}{l}\text { Search \#40 NOT ("addresses"[Publication Type] OR "biography"[Publication Type] OR "comment"[Publication } \\
\text { Type] OR "directory"[Publication Type] OR "editorial"[Publication Type] OR "festschrift"[Publication Type] OR } \\
\text { "interview"[Publication Type] OR "lectures"[Publication Type] OR "legal cases"[Publication Type] OR } \\
\text { "legislation"[Publication Type] OR "letter"[Publication Type] OR "news"[Publication Type] OR "newspaper } \\
\text { article"[Publication Type] OR "patient education handout"[Publication Type] OR "popular works"[Publication } \\
\text { Type] OR "congresses"[Publication Type] OR "consensus development conference"[Publication Type] OR } \\
\text { "consensus development conference, nih"[Publication Type]) NOT (animals[mh] NOT humans[mh]) }\end{array}$ & $\underline{1277}$ \\
\hline$\# 40$ & Search \#38 AND \#39 & $\underline{1421}$ \\
\hline$\# 39$ & $\begin{array}{l}\text { Search "Pain"[Mesh] OR pain*[tiab] OR ache*[tiab] OR "Pain Threshold"[Mesh] OR "Pain Measurement"[Mesh] } \\
\text { OR "Hyperalgesia"[Mesh] OR hyperalgesi*[tiab] OR allodynia*[tiab] OR "Analgesia"[Mesh] OR analgesi*[tiab] OR } \\
\text { "Pain Perception"[Mesh] OR "Nociception"[tiab] }\end{array}$ & $\underline{570869}$ \\
\hline$\# 38$ & $\begin{array}{l}\text { Search "Schizophrenia and Disorders with Psychotic Features"[Mesh] OR "Schizoid Personality Disorder"[Mesh] OR } \\
\text { "Schizotypal Personality Disorder"[Mesh] OR Schizophreni*[tiab] OR "Dementia Praecox"[tiab] OR "Dementia } \\
\text { Precox"[tiab] }\end{array}$ & $\underline{126370}$ \\
\hline
\end{tabular}

Appendix 1. An example of the search and searchterms, as performed in PubMed. 
Appendix II. Flowchart of the inclusion process of the systematic search.

\section{Clinical pain in schizophrenia - Gwenda Engels}

Search performed: May $2^{\text {nd }} 2013^{*}$

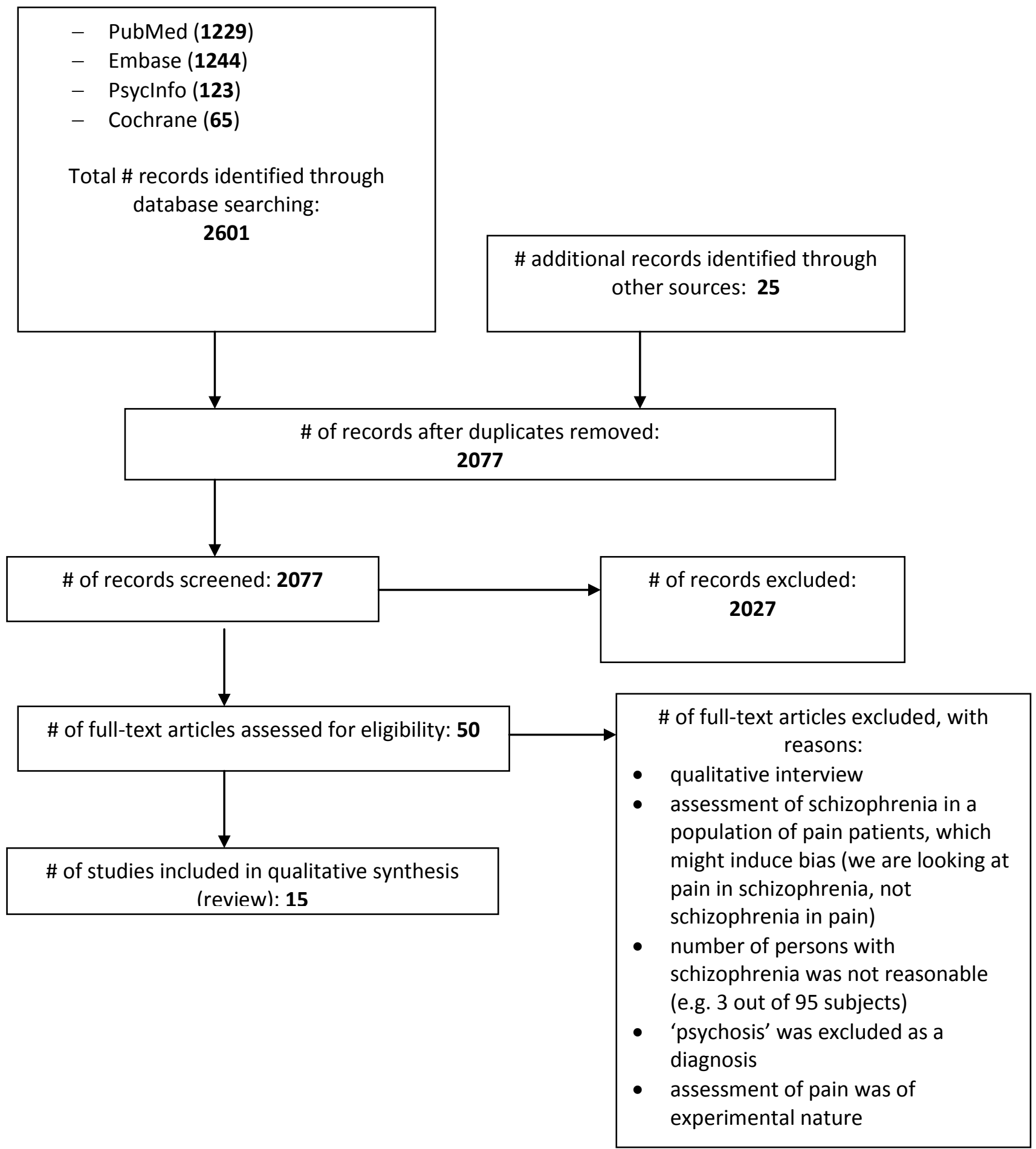

*Systematic search was repeated 1 year after commencement of by GE in order to include most recently published articles. May $2^{\text {nd }} 2013$ was the most recent search. 